\title{
IMPLEMENTASI LOCAL WISDOM EDUCATION DALAM PENDIDIKAN ISLAM SEBAGAI SOLUSI PENGUATAN KARAKTER PATRIOTISME GENERASI MILLENIAL
}

\author{
Nurul Hidayati Amanah \\ Program Studi Pendidikan Agama Islam, IAIN Kediri \\ Email: nurulhdyamanah@gmail.com
}

\begin{abstract}
Abstrak
Artikel ini membahas tentang impelementasi pendidikan Islam yang berbasis kearifan lokal sebagai solusi penguatan karakter generasi millenial. Generasi millenial merupakan generasi dengan usia 17- 36 tahun, akan tetapi dalam artikel ini penulis mengerucutkan pembahasan permasalahan yang dialami oleh generasi millenial yang masih dalam tahap menuntut ilmu, yakni sebagai siswa SMA, mahasiswa, maupun mahasantri pada pondok pesantren. Salah satu permasalahan yang dialami oleh generasi millenial saat ini ialah lunturnya nilai- nilai patriotisme yang diindikasikan oleh beberapa hal, salah satunya yaitu adanya sumpah daulah Islamiyah yang diikrarkan mahasiswa suatu instansi pada tahun 2017. Agar fenomena tersebut tidak semakin meresahkan, pendidikan memiliki fungsi yang penting untuk mencegah hal tersebut tidak semakin meluas. Seperti yang telah kita ketahui, di Indonesia, banyak sekali jenis pendidikan, salah satunya yaitu pendidikan Islam. Salah satu cara untuk menguatkan nilai patriotisme pada generasi millenial yaitu dengan mengintegrasikan nilai identitas nasional dengan konsep pendidikan Islam dengan cara mengaplikasikan FGD (Focus group discussion) yang mirip dengan metode syawir, pembelajaran kreatifitas yang berbasis kearifan lokal, serta pembelajaran karakter berbasis kearifan lokal dan keagamaan.
\end{abstract}

Kata Kunci: Pendidikan Islam, Kearifan Lokal, Patriotisme, Generasi Millenial.

\section{PENDAHULUAN}

Pembahasan tentang generasi millenial selalu menjadi pembahasan yang menarik dalam berbagai perspektif. Generasi millenial merupakan mereka yang berusia 17- 36 tahun(Iffah, 2017: 319) yang kini berperan sebagai mahasiswa, early jobber, serta orang tua muda. Dalam pemaknaan tentang generasi millennial dikerucutkan oleh penulis, yaitu mereka yang saat ini berperan sebagai penuntut ilmu.

Dalam paparan sejarah Islam, peran pemuda dapat dikatakan sangat urgen, mengingat terdapat beberapa kisah yang terdapat dalam Al-Quran yang membahas tentang pemuda. Salah satu kisahnya adalah diabadikan dalam Qs. Al Kahfi ayat 10: (QS. 18:10)

$$
\text { اذاو ى الفتية الى الكهف فقالو ا ربنا اتنا من لدنك رحمة وهيئ لنا من امرنا رشدا }
$$

Artinya: Ingatlah ketika pemuda- pemuda itu berlindung ke dalam gua lalu mereka berdoa, "Ya Tuhan kami, berikanlah rahmat kepada kami dari sisi- Mu dan sempurnakanlah petunjuk yang lurus bagi kami dan urusan kami", 
Ayat tersebut, mengisahkan tentang ashabul kahfi yang berjumlah relatif sedikit, yakni tujuh orang diantara penduduk yang menyembah berhala (Misbah, 2019: 72). Mereka memilih berlindung di gua karena mereka tidak mau kembali ke agama nenek moyang mereka serta menolak menyembah selain Allah SWT. Dari penggalan cerita dalam Qs. Al Kahfi tersebut mengisyaratkan beberapa sikap yang "seharusnya" dimiliki pemuda, yakni berani menghadapi tantangan, tidak mudah tergerus arus, serta memiliki sifat rekasa (rela berkorban)

Dalam konteks negara Indonesia, pemuda memiliki peranan yang sangat penting pula dalam kemerdekaan Indonesia, dimulai dari peperangan melawan penjajah yang terorganisisir dalam pendidikan, pembentukan organisasi pergerakan yang bermuara pada terciptanya sumpah pemuda tahun 1928, maupun bekerjasama dengan golongan tua dalam merumuskan konsep kemerdekaan Indonesia tahun 1945. Melalui analisa catatan sejarah yang ditulis oleh Clifford, menyebutkan bahwa lembaga pendidikan yang pada masa itu berbentuk Santri Insurreaction atau pemberontakan santri dalam kurun waktu 1820-1880 menghasilkan beberapa pemberontakan terhadap Belanda (Hamid, 2010: 91), yakni Perang Paderi(1821- 1828), Perang Diponegoro, Perang Banjarmasin, Perang Aceh, dan Perang Banten. Hal tersebut merupakan implementasi dari nilai patriotisme dalam konteks masa lalu.

Namun, nilai patriotisme di Indonesia akan berbeda konteksnya dengan situasi sekarang, mengingat zaman sekarang sudah tidak menghadapi "perang” yang tampak, tetapi situasi yang sedang dihadapi adalah arus global yang semakin deras. Sebagai contoh, beberapa waktu yang lalu kita disuguhkan dengan fenomena sumpah mahasiswa tentang daulah Islamiyah yang jelas- jelas bertentangan dengan isi sumpah pemuda pada tahun 1928, bahkan apabila kita mengutip dari catatan akan muncul konsep bahwa angkatan generasi 45 sebagai generasi pejuang, angkatan 66 sebagai generasi pembangungan, dan angkatan 98 dianggap sebagai generasi penikmat, atau bahkan penghancur (Iswan dkk, 2018). Apabila hal ini dibiarkan secara terus menerus, akan dimungkinkan muncul tindakan radikalisme yang bertentangan dengan nasionalisme dan patriotisme terhadap negara Indonesia, yang pada dasarnya nasionalisme dan patriotisme merupakan elemen faktual yang mengandung eksistensi bahwa negara memiliki kepentingan moral dalam membangun bangsa agar saling berkesinambungan dalam membangun bangsa (Samidi, 2020: 32).

Adanya fenomena sumpah daulah Islamiyah tersebut, menurut hemat penulis disebabkan oleh beberapa faktor, yaitu adanya keinginan untuk mencari jati diri serta sikap dasar generasi millenial yang cenderung menyukai hal instan (dalam hal ini adalah adanya pemahaman agama). Sebagai upaya preventif agar fenomena- fenomena yang berpotensi merongorong keutuhan bangsa tersebut, pendidikan memiliki urgensi yang signifikan dalam pembentukan karakter lokal bangsa Indonesia yang dapat disampaikan melalui aspek afektif, kognitif, maupun psikmotorik. 
Di Indonesia, banyak sekali jenis pendidikan yang ditawarkan yang memiliki tujuan yang sama, yakni membentuk manusia yang ulul albab. Salah satu bentuk pendidikan yang ditawarkan adalah pendidikan Islam yang sampai saat ini selalu relevan untuk dibahas karena beberapa hal dasar, yaitu pendidikan melibatkan sosok manusia yang senantiasa berakal dan dinamis (baik dalam pendidik, peserta didik, maupun penanggungjawab pendidikan). Sikap yang pertama inilah yang membedakan manusia dengan hewan (Atang dkk, 2015: 219). Selain itu, alasan kedua adalah dibutuhkan inovasi- inovasi dalam pendidikan Islam yang sebagai penyeimbang perkembangan sains dan teknologi, serta tuntutan globalisasi yang melebutkan sekat- sekat agama, ras, budaya, serta falsafah suatu bangsa. Maka dari itu, dalam makalah ini penulis ingin menawarkan sebuah solusi yang dapat digunakan dalam mengupayakan penguatan karakter patriotisme bagi generasi millenial.

\section{ISI DAN PEMBAHASAN}

\section{A. Local Wisdom Education}

\section{Local Wisdom Education}

Sebelum membahas lebih lanjut mengenai local wisdom education, penulis ingin memaparkan pengertian local wisdom education, yakni pendidikan yang berbasis kearifan lokal. Apabila ditarik dari segi bahasa penyusunnya, terdapat dua aspek yang dapat dijabarkan pengertiannya, yaitu pendidikan dan kearifan lokal. Pendidikan berasal dari kata "didik" yang mendapat awalan me- sehingga menjadi "pendidik" artinya memelihara dan memberi latihan. Dalam memelihara dan memberi latihan diperlukan adanya ajaran, tuntunan, dan pimpinan mengenai akhlak dan kecerdasan pikiran (Nurul, 2019: 1). Apabila diartikan secara lebih luas, pendidikan dapat diartikan sebagai rangkaian metode- metode tertentu sehingga dihasilkan pengetahuan, pemahaman, dan tingkah laku yang sesuai dengan norma, nilai- nilai dan kebutuhan. Sedangkan, konsep kearifan lokal mengacu pada tatanan sosial budaya dalam bentuk pengetahuan, norma, peraturan, dan keterampilan masyarakat di suatu wilayah untuk memenuhi kebutuhan hidup bersama yang diwariskan secara turun temurun (Dyah dkk, 2019: 20). Kearifan lokal dapat dikembangkan masyarakat agar terjadi keseimbangan dan keteraturan sosial di lingkungan sekitarnya, karena pada dasarnya nilai budaya, tradisi, adat, dan sosial keindonesiaan dalam sinerginya dengan khazanah Islam dan ilmu pengetahuan merupakan sumber utama bagi peradaban dunia masa depan. (Edi, 2020: 186)

Sedangkan calistion atau local wisdom education merupakan sebuah inovasi dalam dunia pendidikan yang memuat konsep kearifan lokal Indonesia. Dalam hal ini, terdapat 
beberapa metode yang dapat digunakan, yaitu FGD atau Focus Group Diascussion yang sesuai dengan Qs. Ali Imran ayat 159, Calistion Creativity yang sesuai dengan konsep attarbiyah, serta Calistion Character Building yang sesuai dengan konsep at- ta'dib.

\section{Pendidikan Islam}

Pendidikan berasal dari kata "didik" yang mendapat awalan me- sehingga menjadi mendidik, yang artinya memelihara dan memberi latihan (Nurul, 2019: 9). Dalam pengertian yang lebih luas, pendidikan diartikan sebagai pembiasaan, pembelajaran, peneladanan, serta bukan sebatas penyekolahan (schooling) (Syaiful, 2018: 236). Dari pengertian diatas, penulis mengambil kesimpulan bahwa pendidikan merupakan sebuah usaha yang dilakukan secara sadar untuk mengembangkan pengetahuan, pemahaman, serta tingkah laku yang sesuai dengan nilai dan norma untuk mengembangkan potensi manusia secara lahir dan batin.

Dalam konteks Islam, pendidikan secara bahasa ada tiga kata yang digunakan, yaitu at- tarbiyah, at- ta'lim, dan at- ta'dib. (Nurul, 2019: 10). Konsep at-tarbiyah mengacu pada penambahan keterampilan peserta didik, sedangkan konsep at-ta'lim mengacu pada konsep transfer of knowledge, sedangkan konsep ta'dib mengacu pada pola pengajaran tingkah laku kepada peserta didik. Ibrahimi mengatakan bahwa pendidikan Islam dalam pandangan Islam sebenarnya adalah suatu sistem pendidikan yang memungkinkan seseorang dapat mengarahkan kehidupannya sesuai dengan ideologi Islam, sehingga ia dapat membentuk karakter dirinya sesuai dengan ajaran Islam. Sedangkan lebih lanjut, Ahmad Marimba menyatakan bahwa pendidikan Islam bimbingan jasmani, rohani berdasarkan kepada hukum- hukum Islam menuju kepada terbentuknya kepribadian utama menurut Islam (Nurul, 2019: 11). Berdasarkan pengertian- pengertian diatas, penulis memberikan pengertian tentang pendidikan Islam, yaitu proses memperoleh ilmu pengetahuan dan nilai keislaman kepada peserta didik dengan menggunakan metode tertentu untuk mencapai kesempurnaan hidup di dunia dan diakhirat.

Dalam adagium ushuliyah terdapat kaidah الاموربمقاصدنا yang menyatakan bahwa setiap aktivitas memiliki orientasi atau tujuan tertentu. Adagium ini mengisyaratkan bahwa pendidikan Islam juga harus memiliki tujuan yang ingin dicapai. Karena itulah tujuan pendidikan Islam harus dirumuskan terlebih dahulu sebelum merumusukan halhal yang lain dalam pendidikan Islam. Menurut Abdullah, pendidikan Islam memiliki beberapa tujuan, diantaranya adalah: (Nurul, 2019: 14) 
a. Tujuan secara jasmani, yakni membentuk mempersiapkan manusia menjadi khalifah dimuka bumi

$$
\text { (و اذقال ربك للملئكة انى جا عل فى الار ض خليفة ) }
$$

b. Tujuan secara rohani, yaitu meningkatkan jiwa kesetiaan hanya kepada Allah semata.

c. Tujuan secara akal, yaitu menemukan kebenaran dan sebab- sebab dengan telaah kekuasaan Allah dengan menggunakan akal

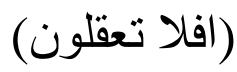

d. Tujuan pendidikan sosial, yaitu membentuk kepribadian yang utuh dari roh, tubuh, dan akal. Identitas individu disini tercermin dalam sebagai manusia yang hidup dalam lingkungan masyarakat yang plural dan jamak.

Apabila berorientasi pada tujuan pendidikan diatas, maka kita dapat menarik kesimpulan bahwa pendidikan seharusnya dilakukan secara berkesinambungan yang sesuai dengan konsep من المهذ الى اللهـ dan sesuai dengan konsep pendidikan sepanjang hayat (long life learning). Sehingga agar mencapai tujuan yang demikian, diperlukan inovasi- inovasi yang mampu menjawab tantangan jaman serta dapat menjadi solusi preventif bagi permasalahan- permasalahan yang muncul seiring dengan berkembangannya zaman.

\section{B. Patriotisme dalam Al- Quran dan Hadits}

1. Konsep Dasar Patriotisme

Sebagai salah satu bagian dari nasionalisme, patriotisme diartikan sebagai sikap yang "rela berkorban". Merry mengungkapkan patriotisme mengarah pada keterkaitan atau simpati afinitas yang dimiliki oleh seseorang terhadap tanah air mereka sehingga menimbulkan keterikatan dan kebanggan secara psikologis (Samidi dkk, 2020: 32). Lebih lanjut JJ Rosseau, seorang pakar kenegaraan mengatakan bahwa patriotisme merupakan sebuah penopang antara sukarelawan dalam hal ini warga negara terhadap negaranya dengan memiliki gagasan- gagasan kebajikan yang diwarisi dari negaranya (Samidi dkk, 2020: 32). Ungkapan Rosseau ini, apabila kita maknai akan muncul sebuah konsep bahwa tiap- tiap warga negara memiliki gagasan tentang kebajikan yang memuat nilainilai kesetiaan terhadap negaranya.

Sebagai sebuah konsep yang memiliki makna dan peta implementasinya sendiri, Michalinos Zembylas mengatakan bahwa patriotisme dibagi menjadi beberapa jenis, yakni (Samidi dkk, 2020: 33) yang pertama patriotisme republik neoklasik. Patriotime 
jenis ini, dipahami sebagai konsep yang terpisah dari nasionalisme dan dipahami sebagai konsep kebebasan bagi politik dan penguatan kesadaran kewarganegaraan, Kedua, patriotisme komunitarian moderat yang dipahami sebagai konsep yang menyatakan adanya hegemoni pemerintah lebih kuat, ketiga patriotisme liberal moderat yang dipahami patriotisme harus menjadi penengah dalam hal menahan solidaritas dan keanggotaan, keempat, patriotisme moderat yang menyiratkan pemahaman kesetiaan konstitusi sebagai dasar patriotisme.

Di Indonesia, konsep patriotisme seringkali dihubungkan dengan pembukaan UUD 1945 pasal 30 ayat 1, yang menyatakan bahwa "tiap- tiap warga negara wajib dan berhak dalam pertahanan dan bela negara”. Konsep bela negara yang erat kaitannya dengan patriotisme ini tidak lantas diartikan secara mentah dengan menghalalkan segala cara, tapi tetap harus berdasarkan pada batas- batas tertentu. Dalam dunia pendidikan, mengajarkan patriotisme merupakan tuntutan karena tujuan utamanya ialah agar warga negaranya memiliki identitas dan mencintai negara. Beberapa pendapat mengatakan, pengajaran konsep patriotisme ini seringkali dihubungkan dengan pembelajaran kewarganegaraan yang berorientasi pada true patriotisme (patriotisme yang tidak hanya mengandalkan kekuatan militer) untuk menjaga keutuhan Negara Kesatuan Republik Indonesia. Padahal menurut hemat penulis, pengajaran tentang patriotisme ini dapat dimasukkan dalam aspek- aspek materi atau mata pelajaran lain dengan orientasi true patriotisme yang sama, baik diimplementasikan secara tersirat maupun secara terangterangan yang akan dibahas lebih lanjut dalam poin selanjutnya.

2. Patriotisme persepektif Al- Quran dan Hadits.

Ketika membahas tentang patriotisme, aspek yang paling dominan dan melekat adalah aspek yang berkaitan negara. Berdasarkan perspektif tersebut dalam al- Quran, paling tidak ada beberapa terminology yang saling berkaitan, yakni balad(wilayah), sya'ab (bangsa), serta ulil amri (pemerintahan). Ketiga terminology ini masing- masing terdapat dalam surat yang berbeda, yang pertama yakni balad, konsep balad ini terdapat dalam Qs. Al- Balad (QS. 90: 1)

Artinya: Aku bersumpah dengan negeri ini (Mekah)

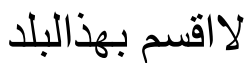

Dari ayat tersebut, kata merujuk pada pengertian, negeri yang dalam hal ini adalah Mekah, yang dapat diartikan sebagai "wilayah mekah". Wilayah dalam konteks suatu negara merupakan unsur pokok, yakni menjadi tempat tinggal rakyat dengan batas- batas tertentu. Sedangkan, dalam unsur negara yang lainnya terdapat konsep sya'ab yang 
berarti bangsa- bangsa. Dalam Qs. Al Hujurat ayat 13 terdapat kata “شعبا" yang merupakan jamak dari pengertian "bangsa- bangsa" yakni sebuah unsur negara yang berisi pengungkapan adanya persamaan nasib dalam sebuah warga negara dan konsep yang terakhir yang menjadi bagian dari unsur- unsur negara adalah ulil amri atau pemerintahan yang ditaati oleh rakyat.

Sedangkan, dalam al- Quran, konsep patriotisme(rela berkorban) tidak dijelaskan secara gamblang. Akan tetapi pemaknaan patriotisme seringkali diwakilkan dengan kata “jihad” seperti yang terdapat dalam Qs. At Taubah ayat 41 (QS. 9: 41)

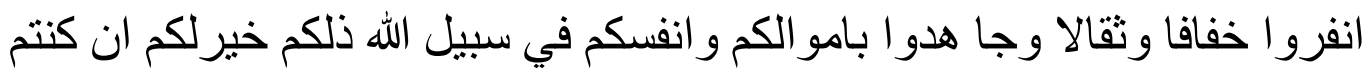

Artinya: Berangkatlah kamu baik dengan rasa ringan maupun dengan rasa berat, dan berjihadlah dengan harta dan jiwamu di jalan Allah, yang demikian itu lebih baik bagimu jika kamu mengetahui.

Berjihad sebagai terminology yang dekat dengan rela berkorban atau jiwa patriotik tidak lantas dimaknai untuk menghalalkan segala cara yang dapat dilakukan untuk membela negara, dalam hal ini menggunakan kekerasan misalnya. Akan tetapi, terdapat konteks dan batasan tertentu. Dalam ayat tersebut juga telah dipaparkan bahwa rela berkorban untuk negara tidak hanya menggunakan tenaga saja, akan tetapi juga menggunakan hal- hal yang lain sesuai dengan konteks yang ada, misalnya dalam konteks pendidikan memiliki jiwa yang rekasa dalam menuntut ilmu juga merupakan salah satu pencerminan dari sikap rela berkorban, seperti halnya yang dikatakan oleh Imam Syafii, "Barangsiapa yang tidak tahan dengan sulitnya menuntut ilmu, maka bersiaplah menanggung kebodohan", ketika maqolah tersebut ditarik dalam konteks rela berkorban maka akan menjadi salah satu bukti bahwa berjihad tidak hanya sebatas hal- hal yang berkaitan dengan "militerisme" dan perang- perangan.

Patriotisme sebagai bagian dari konsep nasionalisme, telah beberapa kali dibahas dalam Hadist. Apabila merujuk pada konsep "hadits" ini, sebagian dari kita akan teringat حب الوطن من pada ungkapan yang seringkali diyakini sebagai prophet legislation, yakni yang berarti cinta tanah air sebagian dari iman. Akan tetapi, ketika mempelajari ilmu hadist, sebagian ulama menyatakan bahwa ungkapan tersebut bukanlah sebuah hadist karena memiliki sanad yang palsu meskipun memiliki makna matan yang kuat (Ali, 2016: 52). Dalam perspektif ilmu hadist, bahwa palsunya sebuah sanad, tidak lantas menjadikan kebathilan matannya(Ali, 2016: 53) sehingga terdapat hadist lain yang ditafsirkan memiliki makna yang dekat dengan konsep rela berkorban, yang merupakan 
bagian dari cinta tanah air yaitu hadits yang diriwayatkan oleh Ibn Abi Hatim (Ali, 2016: 53):

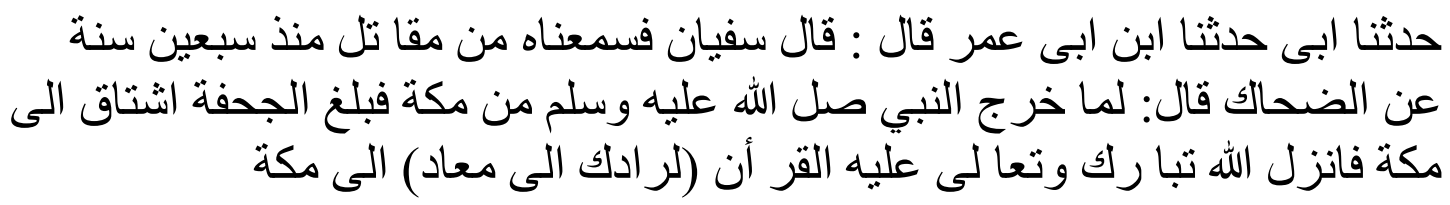

Artinya: Dari Ad- dhahak, beliau berkata: ketika Rasulullah saw keluar dari kota Makkah, lalu sampai pada juhfah (tempat diantara Mekkah dan Madinah) beliau rindu dengan Makkah, maka Allah swt menurunkan ayat, ... "sungguh Allah swt akan mengembalikanmu ditempat kembali"

Hadits tersebut, diamini oleh banyak penafsir al- Quran, seperti yang halnya Ibnu

'Asyur, dan Sayyid Quttub yang ditulis oleh Quraisy Shihab dalam Tafsir al- Misbah (Ali, 2016: 54).

Berangkat dari konsep kecintaan terhadap negara, maka sikap patriotisme sebagai bagian dari cinta tanah air dapat dimaknai dapat diwujudkan dengan berbagai hal yang maslahat dan positif, juga dapat dipelajari atau dibiasakan melalui berbagai aspek, termasuk pendidikan.

\section{Generasi Millenial}

1. Realitas Generasi Millenial.

Millenial merupakan istilah cohort dalam demografi, yang merupakan kata benda yang berarti pengikut atau kelompok (Iffah, 2017: 320). Saat ini ada beberapa pengelompokan dalam demografi, yakni baby boomer (lahir tahun 1946- 1964), Gen- X (Lahir tahun 1965- 1980), Millenial (lahir tahun 1981- 2000), serta Gen Z- (Lahir pada tahun 2001- sekarang). Klasifikasi pengelompokan ini apabila ditelaah lebih lanjut dalam perundang- undangan, pemaknaanya lebih dekat dengan usia pemuda. Dalam kaitannya dengan pemaknaan tersebut, penulis menggambarkan peran pemuda, yakni seseorang yang memiliki semangat dan asset yang terpenting dari sebuah negara, pemuda dianggap memiliki struggle yang luar biasa dalam mewujudkan cita- cita agama dan negaranya (Misbahul, 2019: 75).

\section{Local Wisdom Education dalam Pendidikan Islam sebagai Solusi Penguatan Karakter Patriotisme Millenial}

Berangkat dari pemaparan permasalahan tentang patriotisme dan permasalahan yang dihadapi pemuda dalam latar belakang, maka penulis memiliki perspektif solusi yang ditawarkan dalam rangka untuk menguatkan nilai karakter patriotisme pemuda. Seperti yang telah dibahas dalam poin- poin sebelumnya, menurut hemat penulis sikap patriotisme dalam al- Quran tidak sebatas tentang pengertian yang dekat dengan militerisme. Namun, lebih dari 
itu,sikap patriotisme dapat diimplementasikan dalam berbagai makna dan konteks yang memiliki unsur- unsur rasa rela berkorban, salah satunya melalui pendidikan Islam dengan menanamkan kecintaan pada identitas atau jati diri bangsa termasuk dengan mengimplementasikan local wisdom education. Pendeknya, apabila seseorang (khususnya peserta didik) telah dilatih melalui hal- hal kecil, maka dimungkinkan akan dapat nilai patriotic akan melekat dalam dirinya. Pendidikan yang berkaitan dengan karakter tidak bisa jika hanya diajarkan melalui pengetahuan saja, melainkan harus berdasarkan pembiasaan sehari- hari (Fathul, 2018:9). Adapun solusi yang ditawarkan penulis dalam rangka penguatan karakter patriotisme adalah sebagai berikut:

1. Penerapan metode FGD atau Focus Group Discussion, Metode FGD sama dengan metode syawir (musyawarah) yang juga merupakan salah satu karakter dan identitas diri bangsa, seperti halnya bunyi pancasila sila ke- 4, yaitu kerakyatan yang dipimpin oleh hikmat dalam kebijaksanaan dalam permusyawaratan perwakilan. Juga sejalan dengan Qs. Ali Imran ayat 159 (QS. 3: 159)

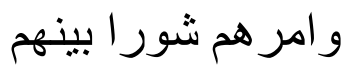

Metode FGD ini, selain sejalan dengan karakter dan identitas bangsa, sehingga dalam implementasinya peserta didik akan senantiasa mengingat ciri khas masyarakat bangsa Indonesia yang merupakan implementasi penguatan nilai patriotisme melalui identitas atau jati diri bangsa, juga sesuai dengan konsep ta'lim dalam pendidikan Islam, yakni yang berkaitan dengan penambahan pemahaman dan pengetahuan peserta didik serta sejalan dengan pengembangan sikap kognitif dalam pendidikan umum.

2. Penerapan Calistion Creativity, yang merupakan pengembangan kreatifitas millenial yang berbasis kearifan lokal, sehingga meskipun mereka cakap dalam pengembangan segala hal sesuai dengan zamannya, ia tidak mengesampingkan patriotisnya. Penerapan calistion creativity ini sejalan dengan konsep tarbiyah dalam pendidikan Islam, yakni berkaitan dengan pengembangan potensi kreatif peserta didik serta sejalan dengan pengembangan sikap psikomotorik dalam pendidikan umum. Selain itu, dalam al quran konsep calistion creativity dibahas secara tersirat dalam Qs. Ar Ra'du ayat 11 yang berbunyi:

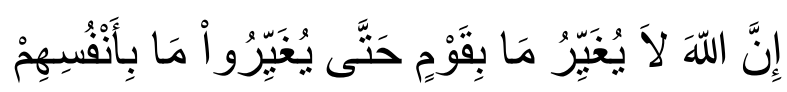

Yang mengindikasikan bahwa Allah menghendaki setiap perubahan yang lebih baik. Akan tetapi, perubahan- perubahan itu harus kitaa usahakan sedemikian rupa, melalui keratifitas dan inovasi- inovasi dapat kita tempuh. Dalam kaitannya dengan patriotisme, 
inovasi yang ada dalam diri peserta didik tidak dimaksudkan untuk merubah secara total segala hal yang berpotensi merusak identitas bangsanya, akan tetapi, kreatifitas itu dimaksudkan untuk kemajuan, naamun sesuai dengan identitas bangsa. Dalam hal ini contoh nyata yang dapat dilakukan adalah integrasi kurikulum berbasis muatan lokal.

3. Calistion Character Building, yakni kegiatan yang berkaitan dengan penanaman karakter- karakter yang dapat menguatkan patriotisme melalui revitalisasi karakter bangsa, seperti halnya jujur, sopan santun, kerjasama, dan lain sebagainya. Penanaman calistion character building ini sejalan dengan konsep ta'dib dalam pendidikan Islam. Apabila karakter yang sesuai dengan kearifan lokal dan jatidiri bangsa ini dibiasakan dengan baik, maka dengan sendirinya, seorang pembelajar akan mencintai tanah airnya, termasuk juga memiliki nilai rela berkorban. Dalam pandangan al- quran, character buiding ini banyak sekali dibahas, terutama padaa Qs. Lukman ayat 12- 24.

\section{KESIMPULAN}

Local Wisdom Education, sebagai salah satu solusi yang dapat diimplementasikan dalam pendidikan Islam diharapkan memiliki kontribusi dalam penguatan nilai patriotisme dalam diri millenial. Penguatan patriotisme ini mengacu pada makna patriotisme dalam al- Quran yang tidak hanya dimaknai sebagai konsep yang dekat dengan "militerisme", akan tetapi dapat dikontekskan dalam berbagai hal, salah satunya dengan penguatan jatidiri dan identitas bangsa yang diselipkan melalui pendidikan. Dalam pendidikan Islam, terdapat beberapa hal yang dapat dilakukan yaitu penerapan FGD, Calistion creativity, serta Calistion Character Building. Sehingga, dari beberapa pemaparan diatas, dapat ditarik kesimpulan bahwa penguatan nilai patriotisme dapat dilatih dan dikuatkan melalui pendidikan pada umumnya, dan pendidikan Islam pada khususnya.

\section{DAFTAR RUJUKAN}

Al- Quran dan terjemahan untuk wanita. 2010. Bandung: Jabal.

Amin, Fathul. 2018. "Pembentukan Karakter Melalui Pendidikan Agama Islam”, Jurnal Tadris, Vol 12 No. 2.

Anwar, Syaiful. 2018. "Pendidikan Islam dalam membangun Karakter Bangsa di Era Millenial", Jurnal Al- Tadzkiyah Vol 9 No. 2.

Fitriana, Dyah Ayu dkk. 2019. Dzikir Pena Santri. Yogyakarta: Belibis Pustaka.

Hakim, Atang Abd. 2015. Metodologi Studi Islam. Bandung: Remaja Rosdakarya.

Hamid, KH. Abdul. 2010. Pemikiran Modern dalam Islam. Bandung: Pustaka Setia. 
Iswan dkk. 2018. "Penguatan Pendidikan Karakter Perspektif Islam dalam Era Millenial IR 4.0", Prosiding Seminar Nasional Pendidikan Era Revolusi, (Jakarta, 24 Maret 2018).

Iyubenu, Edi AH. 2020. Agama adalah Cinta, Cinta adalah Agama. Yogyakarta: Divapress

Rohmaniyah, Nurul. 2019. Konsep Pendidikan Islam dalam Perspektif KH. Wachid Hasyim. Skripsi: STITMA TUBAN.

Samidi, R. dkk. 2020. "Analisis Kritis Eksistensi Nilai Patriotisme dalam Pendidikan Kewarganegaraan”, Jurnal Harmoni Vol 5 No. 1

Walidah, Iffah al. 2017. “Tabayyun di Era Generasi Millenial”, Jurnal Living Hadis, Vol 2 Nomor 1.

Wani, Misbahul. 2019. "Pemuda dalam Al- Quran dan Sunnah", Jurnla Studi Ilmu Quran dan Hadits Vol 13 No 1

Ya'qub, H. Ali Musthafa. 2016. Cara Cermat Mengamalkan Hadits. Tangerang: Maktabah Darussunnah 